\title{
Brexit, Ireland and the World Trade Organization: possible policy options for a future UK-Australia agri-food trade agreement
}

Article

Accepted Version

Swinbank, A. (2018) Brexit, Ireland and the World Trade Organization: possible policy options for a future UK-Australia agri-food trade agreement. Australian Journal of International Affairs, 72 (4). pp. 371-383. ISSN 1035-7718 doi: https://doi.org/10.1080/10357718.2018.1451985 Available at https://centaur.reading.ac.uk/76568/

It is advisable to refer to the publisher's version if you intend to cite from the work. See Guidance on citing.

Published version at: https://doi.org/10.1080/10357718.2018.1451985

To link to this article DOI: http://dx.doi.org/10.1080/10357718.2018.1451985

Publisher: Informa UK Limited

All outputs in CentAUR are protected by Intellectual Property Rights law, including copyright law. Copyright and IPR is retained by the creators or other copyright holders. Terms and conditions for use of this material are defined in the End User Agreement. 


\section{CentAUR}

Central Archive at the University of Reading

Reading's research outputs online 


\title{
Brexit, Ireland and the WTO: Possible Policy Options for a Future UK-Australia Agri-food Trade Agreement
}

\author{
Alan Swinbank \\ University of Reading
}

\begin{abstract}
Prior to the United Kingdom's accession to the then European Economic Community (EEC), in 1973, Australia was a significant supplier of Britain's food. Membership of the EU resulted in trade diversion, closing the British market to Australian sugar for example. This paper questions whether the UK's exit from the EU ("Brexit") might usher in a new agri-food trade regime, restoring Australian farmers' access to the British market, or whether other opposing political economy considerations might prevail. Would the UK unilaterally adopt free trade? Can a comprehensive Free Trade Area (FTA) agreement between Australia and the UK, including agri-food products, be negotiated? Any new relationship will need to reflect the UK Government's stated preference for a frictionless border with EU27 (particularly on the island of Ireland), the WTO rule-book, and the interests of the UK's farm lobbies, as well as the UK's quest for 'free trade' with the wider international community.
\end{abstract}

Key Words: Brexit, agriculture, WTO, trade, Ireland

Summary at a glance: Trade in agricultural goods will be affected by Brexit (the UK's departure from the European Union) particularly over the UK's border with the Republic of Ireland, and potentially raises new trading possibilities for Australia. 
As we leave the European Union, we will negotiate a new, comprehensive, bold and ambitious free trade agreement with the EU, but we will also seize the exciting opportunities to strike deals with old friends and new partners. At this summit [the G20 in Hamburg], I held a number of meetings with other world leaders, all of whom made clear their strong desire to forge ambitious new bilateral trading relationships with the UK after Brexit. This included America, Japan, China and India. This morning, I welcomed Australian Prime Minister Turnbull to Downing Street, where he also reiterated his desire for a bold new trading relationship. Theresa May, House of Commons, 10 July 2017.

\section{Introduction}

As a result of a referendum on its membership of the European Union (EU) on 23 June 2016, in which $51.9 \%$ of votes caste were to leave the EU and $48.1 \%$ to remain, on a turnout of $72.7 \%$ (The Electoral Commission, 2016), the United Kingdom (UK) is set to leave the EU ("Brexit"), possibly as early as 11pm (British time) on 29 March 2019. Quite what this will mean for the UK's future trade relations with the EU, and the rest of the world, is yet to be determined. This paper focuses on the political economy constraints, and World Trade Organization (WTO) rules, that will influence the outcome, particularly with regard to trade in agricultural commodities and food and drink products (see also Swinbank, 2017a \& Swinbank, 2017b), and on the quest for a Free Trade Area (FTA) with Australia.

Two issues are highlighted. First, that although the EU's common agricultural policy (CAP) has undergone a number of reforms since the 1990s, and consequently is rather less trade distorting than the "old" CAP of the 1970s and 80s (Swinbank \& Daugbjerg, 2017), it is still characterised by excessively high tariffs on a number of products: on beef, butter and cheese, and sugar for example. Second, that a rather critical border between a post-Brexit UK and the remaining members of the EU (referred to as EU27 in this paper) is the one on the island of Ireland dividing the Republic of Ireland from the United Kingdom of Great Britain and Northern 
Ireland. How to keep that border open, and not to return to The Troubles ${ }^{\mathrm{i}}$ of the past, is a major concern.

The paper proceeds as follows: Section 1 sets the scene by recalling the impact on Australian agriculture of the UK's accession to the European

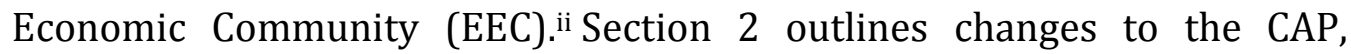
prompted in large part by international pressure in the Uruguay Round. These changes did not however extend to subsequent reductions in agricultural tariffs. Section 3 discusses some of the difficulties the UK is encountering in attempting to redefine its post-Brexit trade relations with EU27, emphasising in particular the high import tariffs that are still charged on many CAP products and the difficulties this might cause for agri-food trade over the Irish border. With these constraints in mind, Section 4 asks what sort of agri-food trade deal for Australia, if any, might emerge; whilst Section 5 concludes.

\section{1: 1973 and Accession of the UK to the EEC}

The United Kingdom's accession to the EEC in 1973 -and a phased harmonisation of the UK's farm support and agricultural tariffs with those of the EEC which was to be completed on 1 January 1978- led to considerable trade diversion. Prior to accession, the UK had been a major market for Australia's agricultural exports, but for several products these export opportunities were closed, as illustrated in Table 1. Whilst New Zealand obtained concessions on butter, and for a limited period for cheese (Lodge, 1982), no similar arrangements were put in place for other developed countries. The developing country suppliers of raw cane sugar under the Commonwealth Sugar Agreement, for refining in the UK, were accommodated, but not Australia (Webb, 1977).

Insert Table 1 about here

Zeros do not dominate the last column of Table 1 because of trade concessions negotiated with the EU. In the Tokyo Round of multilateral trade negotiations under the auspices of the General Agreement on Tariffs 
and Trade (GATT), launched in 1973 and concluded in 1979, Australia (and others) had obtained Tariff Rate Quotas (TRQs) enabling it sell limited quantities of beef and cheese to the EU without paying the EU's full variable import levy. With the introduction of a common support policy for sheepmeat in 1980 New Zealand had negotiated a Voluntary Restraint Agreement (in effect a TRQ) with the EU, with the arrangements later extended to Australia and others, reducing the EU's tariff from $20 \%$ to, eventually, $0 \%$ on these supplies. In the Uruguay Round these TRQs were incorporated into the EU's Schedule of Commitments. iii Quite how a postBrexit UK, and EU27, will share, or otherwise assume responsibility for these TRQs is as yet unknown (and is not explored in this paper).

Australia's discontent with the EEC, and in particular with its CAP, has been widely documented (e.g. Benvenuti, 1999, Bureau of Agricultural Economics, 1985). In March 1978 for example, Vic Garland, then Minister for Special Trade Representations, claimed: 'Australia is the country worst affected by the enlargement of the EEC and its common agricultural policy'. In his view, the EEC was denying Australia 'the opportunity, the right, to compete in its markets. Worse, the EEC is disposing of the surpluses caused by its policies at heavily subsidised prices on third markets in which we would otherwise sell our products.'

\section{2: The Uruguay Round and CAP Reform}

Although highly critical of the CAP, and strongly supportive of the USA's opening stance in the Tokyo Round on liberalising trade in agricultural products, Australia itself had limited leverage in that it was willing to offer little by way of easier access for industrial products onto its markets. Up to that time Australia had intervened extensively in its economy — but much more so in the manufacturing sector than in agriculture. Thus it suffered a 'credibility gap in its campaign for fairer and freer trade in agriculture' (Capling, 2001: 93). In the face of a steadfast European defence of its agricultural policy, in 1977 the Americans agreed to delink the negotiations on agriculture from those on industrial tariffs, allowing the 
Tokyo Round to be concluded without significant progress on agriculture (Daugbjerg \& Swinbank, 2009: 78-9).

The election of a Labor government in 1983 led to a fundamental reappraisal of Australian policy, including financial deregulation, floating the currency, and 'dramatic unilateral tariff reductions' in 1988 and 1991 (Capling, 2001: 96). Nonetheless, some farm sectors continued to receive support into the 1980s. Thus dual pricing systems (under which Australian consumers paid higher prices than those earned from exports) raised farm-gate prices for some products, including sugar cane and milk, 'by significant amounts', and in 1986-87 a large deficiency payment was made to wheat producers (Mauldon, 1990: 310).

In the early 1980s, prior to the launch of the Uruguay Round at Punta del Este in September 1986, Australian officials developed 'an imaginative new approach to multilateral diplomacy' (Capling, 2001: 105). Australia emerged as a staunch advocate of free trade, and assisted in the formation, in August 1986, of the Cairns Group of likeminded 'fair traders' determined to play an active part in the forthcoming negotiations. Nonetheless, as Kenyon and Lee (2006: 73) concede, 'the extent to which members of the Cairns Group protected domestic agriculture, and their willingness to reform domestic support policies, varied significantly'.

It was, however, the USA and the EU that dominated the Uruguay Round negotiations. Scholars will no doubt continue to debate the causal factors that led to the inclusion of an Agreement on Agriculture in the package of agreements concluded in Marrakesh in 1994, and the extent to which these negotiations prompted the EU, in 1992, to undertake its first significant reform of its CAP (the MacSharry Reform). But the US and EU's resolve that the whole Uruguay Round package had to be treated as a Single Undertaking, explicitly linking the agricultural negotiations to progress in other dossiers, was probably a decisive factor (Daugbjerg \& Swinbank, 2009: 90-3).

In a series of 'reforms', beginning with that of 1992, the EU has made significant changes to the CAP (Swinbank \& Daugbjerg, 2017). 
Despite this the CAP's core raison d'être remains that of supporting farm incomes, however imperfectly defined or targeted. And one defining element of the "old" CAP remains in place. Following the initial, and limited, reductions in import tariffs negotiated in the Uruguay Round, no significant MFN (most-favoured-nation) tariff reductions have subsequently been implemented. CAP reform has embraced domestic support provisions, but has not extended to tariff reductions. ${ }^{\text {iv }}$ At one stage in the Doha Round negotiations it did seem possible that the higher tariffs could be reduced by up to 70\% (WTO, 2008), but with the Round in the doldrums that prospect appears to have been lost. Consequently MFN tariffs on a number of products (dairy, red meats, sugar, for example) remain prohibitively high, as illustrated later in this text, and imports are only possible under concessional terms (Swinbank, 2017b).

WTO rules provide for three systems of concessional access. First, WTO Members can discriminate in favour of developing countries, provided they do so on a MFN basis. Thus, under its Everything but Arms (EBA) scheme, the EU offers duty and quota free access for products originating within the Least-developed Countries (LDCs), giving access for example for sugar and rice to the EU's protected market. Second, as noted above, in the Uruguay Round various country-specific TRQs were incorporated within the Schedules of Commitments of various WTO members, including the EU; but these give Australia rather limited access to the EU market (Hussey \& Tidemann, 2017: 104-6). Third, and of particular relevance to this paper, GATT Article XXIV allows WTO members to form Free Trade Areas (FTAs) and Customs Unions, within which products can move freely (although for FTAs this relates only to originating products, necessitating potentially complex rules of origin). In Section 3 the paper considers the prospects for future UK-EU27 trade relations, whilst Section 4 assesses the aspirations of Australia's agri-food sector for a UK-Australia FTA.

\section{3: Post-Brexit UK-EU27 Trade Relations}


Although the UK triggered Article 50 of the Treaty on European Union on 29 March 2017 -implying that the UK will leave the EU in March 2019 unless other arrangements are negotiated - very little is yet known about the measures that will govern trade between the UK and EU27 following Brexit.

By December 2017 it was more-or-less agreed by the EU27's negotiator and the British Government - but not yet formally ratified by treaty - that there was a need for a transition period (although the British preferred to refer to an implementation period) of about two years to avoid a 'cliff-edge' scenario in March 2019. During this transition, EU law (e.g the CAP) would continue to apply in the UK, the UK would be bound by the EU's trade agreements with Third Countries (i.e. no scope for implementing an Australia-UK FTA in that period), and the UK would have no say in EU decision making (Joint Report, 2017). A new UK-EU27 trade agreement, to apply from the end of the transition period, could then be negotiated.

It is still possible that the UK will exit the EU - either by accident or design - without an alterative UK-EU27 trade pact in place (some commentators, depending on their political persuasion, talk of a 'hard' Brexit, others of a 'clean' Brexit). The Article 50 negotiations did not start well, and there is no guarantee that they can be concluded successfully. Indeed, in the past, the British Government has said that 'no deal for the UK is better than a bad deal for the UK' (HM Government, 2017a: 65). Moreover, hard-core Brexiteers remain adamant that a clean break is required, and was mandated by the referendum result. A number of prominent economists support this stance (see Economists for Free Trade, 2017). Given the fluid and fervid nature of current UK politics, such an outcome cannot be discounted. Under such circumstances trade between the UK and EU27 would be regulated by WTO rules; but the UK would be free to unilaterally reduce its MFN tariffs (i.e. pursue free, or freer, trade) and/or negotiate FTAs with low cost agricultural producers such as Australia. 
The UK Government has consistently said that, although exiting the EU means leaving both the Customs Union and Single Market (see Box 1), it is seeking 'a new customs arrangement that facilitates the freest and most frictionless trade possible in goods between the UK and the EU' (HM Government, 2017b: 2). That document talked about 'aligning our approach to the customs border in a way that removes the need for a UKEU customs border'; and of implementing 'technology-based solutions to make it easier to comply with customs procedures' (p. 2). ${ }^{v}$

\section{Box 1: The EU's Customs Union and Single Market}

GATT Article XXIV insists that, to be valid, members of a customs union must ensure that 'duties and other restrictive regulations of commerce ... are eliminated with respect to substantially all the trade between the constituent territories of the union' (my emphasis), and that 'substantially the same duties and other regulations of commerce are applied by each of the members of the union to the trade of territories not included in the union'. In this regard the EU might be characterised as a perfect customs union in that it covers all trade between EU states, and a common external tariff applies on third country imports. In contrast the customs union between the EU and Turkey is only partial in that it does not include agricultural products.

Non-tariff barriers (NTBs) can also restrict trade. Although some regulatory convergence between Turkey and the EU has been agreed, Turkey is not part of the EU's Single Market.

The Single (or Internal) Market is based on EU law rather that WTO agreements. In seeking to achieve the free movement of goods - one of the 'four freedoms' for goods, services, capital and workers - the same regulatory regime applies in all the Member States, or the principle of mutual recognition results in products legally produced in one Member State being accepted throughout the Single Market. With its Customs Union covering all goods, and regulatory harmonisation or equivalence achieved in its Single Market, there is no need to apply border controls on goods within the EU. Once the EU's common external tariff has been paid, imports from third countries are in free circulation in the EU.

Norway, Iceland and Liechtenstein, as members of the European Economic Area (EEA), are part of the EU's Single Market (but not of the Customs Union), and consequently have to accept and apply relevant regulatory provisions adopted by the EU. They have Free Trade Area (FTA) agreements with the EU, rather than customs unions. Moreover, these FTA provisions do not extend to agriculture, and Norway et al. do not apply the CAP. Many of the EU's other FTAs - for example the Comprehensive 
Economic and Trade Agreement (CETA) between the EU and Canada- do not have full coverage of agricultural products.

Both FTAs and customs unions are governed by GATT Article XXIV. Collectively they are referred to as Regional Trade Agreements (RTAs) by the WTO. FTAs differ from customs unions in that only products produced within the FTA benefit from the "free" trading provisions, and partners can maintain their own trade barriers against third country products, necessitating complex rules of origin. The WTO also oversees Preferential Trade Arrangements (PTAs) — such as a Generalised System of Preferences (GSP) - which are not reciprocal: https://www.wto.org/english/tratop e/region e/region e.htm

Both sides in the Article 50 negotiations are insistent that the one land border between EU27 and the UK — straddling the island of Ireland - is of critical importance. With regard to this complex issue, paragraph 49 of the Joint Report (2017) said:

'The United Kingdom remains committed to protecting North-South cooperation [between the two jurisdictions on the island of Ireland] and to its guarantee of avoiding a hard border. Any future arrangements must be compatible with these overarching requirements. The United Kingdom's intention is to achieve these objectives through the overall EU-UK relationship. Should this not be possible, the United Kingdom will propose specific solutions to address the unique circumstances of the island of Ireland. In the absence of agreed solutions, the United Kingdom will maintain full alignment with those rules of the Internal Market and the Customs Union which, now or in the future, support North-South cooperation, the all-island economy and the protection of the 1998 [Good Friday or Belfast] Agreement.'

Agriculture, and the EU's past failure to complete reform of its CAP, present particular difficulties in this regard (Swinbank, 2017b). MFN tariffs on red meats, dairy products, and sugar, are particularly high, as already mentioned above and now illustrated in Table 2. This is not to suggest that EU prices exceed world market prices by these amounts. There is considerable "water" in many of these MFN tariffs, and EU market prices often approximate world levels. But they are the tariffs that EU27 would be obliged to apply on imports from the UK in the absence of a FTA linking EU27 and the UK, as under WTO rules (GATT Article I) EU27 could not 
treat imports from the UK more favourably than imports from any other WTO Member, and vice versa.

\section{Insert Table 2 about here}

Sugar presents a particularly stark example. Ireland no longer produces sugar. Instead it imports sugar (for both direct consumption and manufacturing purposes) from other EU Member States. The EU's import regime is particularly complex, with a number of preferential access schemes (see for example Agbenyegah \& Frawley, 2017: 72-5). This complexity of course extends to processed products containing sugar on which comparably high MFN tariffs apply. The limited imports of sugar into the EU under preferential schemes consist largely of raw cane-sugar for refining, with the UK the main import destination. Australia has access to a small country-specific TRQ, and so its sales of sugar to the EU are very limited.

If the UK and EU27 fail to agree a FTA that includes agriculture, and revert to MFN tariffs, then trade in many agri-food products across the Irish border would be abruptly disrupted Alternative scenarios are conceivable, but —in my judgement- highly unlikely: a) The EU significantly reduces its MFN tariffs on CAP products abating the difficulties envisaged in this text; b) Northern Ireland leaves the UK and unites with the Republic of Ireland within the EU; c) Ireland leaves the EU and aligns its trade with UK agricultural policy as was the case prior to 1973; or d) Northern Ireland becomes a separate customs territory within the UK, aligning its farm tariffs with those of the EU, and necessitating customs controls within the UK between the island of Ireland and Great Britain. The latter corresponds to a rather contentious proposal the EU27's negotiator advanced on 28 February 2018 in suggesting that, in the absence of alternative solutions to keep the border open, it might be necessary for Northern Ireland to remain within the EU Customs Union, and continue to apply the EU's sanitary and phytosanitary rules 'on the production and marketing of agricultural and fisheries products' (European Commission, 2018: 101). However, this would seem to be a 
non-starter, as the UK Government has said it is implacably opposed to any proposal that would fracture the UK's own internal market.

If prohibitively high MFN tariffs on many CAP products are to apply to EU imports from the UK, then shipments from the North of Ireland to the South would almost certainly cease, whereas the outcome for South-North trade would depend on the UK's trade policy stance: the UK could, for example unilaterally reduce the MFN tariffs it applies on one or more products. Currently large volumes of agricultural produce and processed products criss-cross this border as part of complex supply chains. ${ }^{\mathrm{vi}}$

Even if the EU and EU27 negotiate a FTA that includes these goods, it is difficult to believe that Ireland, or the EU farm lobby, would be willing to accept free importation of sugar (and sugar-containing products) from a post-Brexit UK, or for that matter beef or other highly protected CAP products, except under very strict circumstances. Pre-notification of shipments for customs clearance, vehicle number-plate recognition technology, etc., might eliminate the need for a physical border —although EU sources have poured scorn on this idea- but shipments would still face a virtual border at which traders would need to demonstrate that the goods respected rules of origin, pay the appropriate tariff that might apply, and satisfy any regulatory requirements (sanitary and phytosanitary rules for example).

When the two parties to a FTA apply similar, and modest, tariffs on imports from third countries, trade deflection is less likely to be important, and so rules of origin can perhaps be dispensed with. But when one of the two parties (the EU say) imposes high tariffs on a particular product (e.g. sugar) then trade deflection is likely to become a real threat. Under these circumstances restrictive rules of origin would almost certainly be rigorously applied, to ensure the sugar had originated in the UK. But trade deflection can extend to product substitution. The EU would not want to import sugar produced from sugar beet grown in the UK, for example, if the bulk of supplies for the UK's domestic consumption was derived from imported raw cane sugar, displacing British grown product onto the EU27 
market. As foreshadowed in the Joint Report of December 2017, EU27 might insist that the UK applies similar, if not the same, trade regime on third country imports.

Consequently the UK Government's stated objective of achieving 'a new customs arrangement that facilitates the freest and most frictionless trade possible in goods between the UK and the EU', particularly for agrifood products over the Irish border, could conceivably result in the EU demanding that the $\mathrm{UK}$ retains trade restrictions on CAP products comparable to those currently applied, as well as shadowing the EU's regulatory measures. ${ }^{\text {vii }}$ Under these circumstances the UK would not be at liberty to adopt a free (or freer) trade stance, or negotiate its own FTAs with low cost agricultural suppliers such as Brazil or Australia. Although notionally free of the EU's Customs Union and Single Market, and its CAP, the UK would have in place similar trade barriers and would have become, in effect, a satellite state of the EU: indeed some members of the British Parliament have talked about the UK becoming a vassal state. As a satellite state - having still to apply the CAP's trade barriers - it would be unable to strike its own agri-food trade deals around the world, or unilaterally reduce its tariffs.

The other extreme is a 'hard' ('clean') Brexit. With this outcome the UK might have no formal trade links with EU27, other than those contingent on WTO membership. Under these circumstances UK agri-food exports to EU27 would face the EU's prohibitively high MFN tariffs, and a correspondingly 'hard' border would be in place on the island of Ireland, rupturing existing North-South trade links with consequential damage to the agriculture, food and drink industries on both sides of the border.

A 'hard' Brexit could result in a number of trade scenarios. In one extreme outcome the UK might unilaterally opt for free trade, offering duty- and quota-free access to all WTO suppliers, including EU27, without obtaining reciprocal admittance. This might be contrasted with a situation in which the UK adopts a protectionist stance, sheltering its agriculture behind the tariffs on CAP products inherited from its EU membership, 
whilst entering no new trade partnerships with either EU27 or other WTO Members. viii Between these two extremes one might imagine: i) the UK negotiating a single FTA, with Australia for example, offering that country significant preferential access to its protected food markets; through ii) multiple FTAs — with Australia, Brazil, the USA for example - in which the margin of preference for each of its FTA partners would be reduced; to iii) numerous FTAs with virtually all potential suppliers, in which the impact on UK food supplies and prices would be barely different from unilateral free trade.

Other variants can also be envisaged including exclusion of certain products (e.g. beef) from FTAs or with TRQ limits on their access; and partial or selected reductions in MFN tariffs. Quite where in this policy space the UK will end up is far from clear, and the uncertain outcome may well take a decade or more to emerge.

\section{4: Agri-food Trade and a UK-Australia FTA?}

Brexit provides an unprecedented opportunity for the Australian red meat industry to enhance its trading relationship with the UK. Meat \& Livestock Australia

Securing duty free access for Australian raw cane sugar in the forthcoming trade discussions with the UK will provide opportunity for UK refiners to access increased quantities of Australian raw sugar on competitive terms. It will also enable Australian exporters to renew and develop commercial trading arrangements with the UK's sugar refiners. Establishing this environment will create good opportunities to grow Australia's raw sugar trade with the UK once it has exited the EU. The Australian Sugar Industry

Alliance

As noted above, Meat \& Livestock Australia (2017), The Australian Sugar Industry Alliance (2017), and various other agri-food industry groups, in evidence to the Australian Parliament's Joint Standing Committee on Foreign Affairs, Defence and Trade (Parliament of the Commonwealth of Australia, 2017), have expressed optimism that Brexit will provide their industries with an opportunity to expand sales to the UK. Bearing in mind the discussion in Section 3 above, how likely is this? 
It is not just the need to avoid disrupting trade between a postBrexit UK and EU27 -including agri-food products over the Irish border - that suggests an outcome nearer the 'soft' Brexit in which the UK becomes a satellite state of EU27. Other political economy considerations also point to a UK agricultural sector retaining considerable border protection against other WTO suppliers.

The nation is divided geographically, with the devolved administrations in Scotland, Wales, and Northern Ireland more wedded to the idea of supporting farmers than is the central government based in Westminster and Whitehall (Swinbank, 2015). Farmers in these regions are more heavily dependent on extensive livestock production (beef and sheep), for example, than are the majority of farms in England: products that will likely prove uncompetitive in a global open-trading marketplace. As agricultural policy is a devolved responsibility (Keating, 2018), "common frameworks" will be need to, inter alia: 'enable the functioning of the UK internal market, while acknowledging policy divergence; ensure compliance with international obligations; [and] ensure the UK can negotiate, enter into and implement new trade agreements and international treaties' (Defra, 2018: 59). As with Australia's Commonwealth and State governments, it is the United Kingdom that has WTO membership. The $U K$ government in London is negotiating with EU27, and post-Brexit it will have responsibility for determining import tariffs, negotiating trade agreements (e.g. FTAs with EU27 and Australia), and ensuring the UK meets its WTO obligations under, for example, the Agreement on Agriculture and the Agreement on the Application of Sanitary and Phytosanitary Measures. How much influence the devolved administrations can bring to bear on these policy decisions remains to be seen.

In England many Conservative MPs serve rural constituencies and, although the farm vote is small, the farm lobby can draw on significant sympathies. If support is to be withdrawn it is more likely to be the rather more visible taxpayer-funded payments to farmers that would be 
eliminated, releasing money for electorally popular projects such as environmental protection and enhancement (Defra, 2018), or the National Health Service, rather than the much less visible support provided by border protection. Abolition of the latter would deliver no (direct) cash bonanza for the public finances.

What then of Australia's agri-food trade prospects in the event of a hard/clean Brexit? Sugar can again be taken as a case in point.

If: i) the UK negotiates a FTA with Australia, that includes sugar, but ii) fails to do so with other competitive suppliers such as Brazil, and iii) maintains its current MFN tariffs, then Australia will have a clear competitive advantage in the UK market (despite duty and quota free access for the rather higher-cost LDC and EPA suppliers). If the UK also negotiates a FTA with Brazil, then Brazilian cane sugar (and ethanol), with shorter (and cheaper) transport links to the UK, may well hold a competitive advantage over Australian supplies. Finally, if the UK goes for free trade on all agri-food products, including refined sugar, then it may well end up importing refined sugar from EU27 in competition with raw cane sugars from around the world, and what remains of its own sugar beet processing industry. In short, the devil lies in the detail.

In negotiating its own FTA with Australia, EU27 will presumably be mindful of any likely EU27-UK and UK-Australia FTAs that might be negotiated, and what their cumulative impact might be. For example, if EU28 had been willing to offer Australia a duty-free TRQ of $\mathrm{x}$ thousand tonnes of sugar, EU27 might now offer a duty-free TRQ of $(x-y)$ thousand tonnes in the expectation that the UK will offer Australia $y$ thousand tonnes.

In seeking to negotiate an EU-Australia FTA we might confidentially predict that one of the EU's offensive interests in the agri-food domain will be enhanced protection on Australian markets for the EU's extensive list of products bearing Geographical Indications of Origin (GIs), as it has done in FTA agreements with other nations (Moir, 2017). For example, in its submission to the EU Member States for opening negotiations with 
Australia, the European Commission (2017c: 7) said: 'The Agreement should provide direct protection through the agreement of a list of GIs (wines, spirits, agricultural products and foodstuffs), at a high level of protection ..., including ..., enhanced enforcement, co-existence with "bona fide" prior trademarks, protection against subsequent genericness [sic] and the possibility to add new GIs.'

It is less easy to imagine what the UK's offensive interest over agrifood trade in a future FTA with Australia might be, which would enable it to present the overall package as advantageous for the UK's farm, food and drink industries. There are some small tariffs on processed foods imported into Australia that could be eliminated with some advantages for UK-based firms but, unlike their European counterparts, the UK has never been an enthusiastic advocate of GIs. In a recent Consultation paper the British Government has said: 'we have a golden opportunity to help our farmers to grow more, sell more and export more great British food, building on our high quality brand. British food and farming has a world-class reputation for quality' (Defra, 2018: 61). But it is not clear why a FTA with Australia would be particularly helpful in this regard.

\section{5: Concluding Comments}

If the UK and EU27 do agree on a transition period of about two years, in effect extending the UK's de facto membership of the EU's customs union, the UK will not be free to enter into new trading agreements with other partners until 2021. For the present UK Government, however, committed as it is to Brexit, there is a strong political imperative to conclude FTAs as quickly as possible, and certainly before the next General Election scheduled for 2022, to demonstrate to the British electorate the success of its policies. Australia, as a like-minded Commonwealth country, with a liberal trade regime and high product standards, is likely to be a priority candidate, despite its small market in comparison to other, more challenging, FTA candidates such as the USA, Brazil, India and China. But unless the UK is willing to forego protecting its farm sector, an Australia- 
UK FTA that fully embraces agriculture faces considerable opposition in the UK, not least over the future status of the Irish border.

If the UK adopts the advice of the Economists for Free Trade, opting unilaterally for free trade, there will be interesting (perhaps profound) implications for the UK's economy and patterns of trade, but whether Australian agriculture will emerge as a major supplier of the UK's food and drink is a more open question, well beyond the scope of the present paper. The situation in the late 2010 s is quite different to that of the late 1960 s. No longer is the UK the obvious outlet for Australian trade. Australia has newer, closer, and more dynamic markets in Asia-Pacific, and would no longer benefit from Commonwealth Preferences in a free trade UK. 


\section{References}

Agbenyegah, Benjamin K. \& Natasha Frawley (2017), 'The EU sugar industry', in Caroline Gunning-Trant \& Natasha Frawley (eds.) A stocktake of selected agricultural markets of the European Union. Opportunities for Australia, Research Report 17.8 (Canberra: Australian Bureau of Agricultural and Resource Economics and Sciences).

The Australian Sugar Industry Alliance (2017), Submission 55 to the Australian Parliament's Joint Standing Committee on Foreign Affairs, Defence and Trade:

http://www.aph.gov.au/Parliamentary Business/Committees/Joint/Forei gn Affairs Defence and Trade/tradewithUK/Submissions

Benvenuti, Andrea (1999), 'Australia's Battle against the Common Agricultural Policy: The Fraser Government's Trade Diplomacy and the European Community', Australian Journal of Politics and History, 45(2): 181-96.

Bureau of Agricultural Economics (1985), Agricultural Policies in the European Community: Their Origins, Nature and Effects on Production and Trade, Policy Monograph No. 2 (Canberra: Australian Government Publishing Service).

Capling, Ann (2001), Australia and the Global Trade System: From Havana to Seattle (Cambridge: Cambridge University Press).

Daugbjerg, Carsten \& Alan Swinbank (2009), Ideas, Institutions, and Trade: the WTO and the Curious Role of EU Farm Policy in Trade Liberalization (Oxford: Oxford University Press).

Defra (Department for Environment, Food and Rural Affairs) (2018), Health and Harmony: the future for food, farming and the environment in a Green Brexit, Cm 9577 (London: Her Majesty's Stationery Office).

Economists for Free trade (2017), Submission 57 to the Australian Parliament's Joint Standing Committee on Foreign Affairs, Defence and Trade:

http://www.aph.gov.au/Parliamentary Business/Committees/Joint/Forei gn Affairs Defence and Trade/tradewithUK/Submissions

The Electoral Commission (2016), EU referendum results: https://www.electoralcommission.org.uk/find-information-bysubject/elections-and-referendums/past-elections-and-referendums/eureferendum/electorate-and-count-information

European Commission (2017a), Intellectual property rights (including geographical indications), Task Force for the Preparation and Conduct of the Negotiations with the United Kingdom under Article 50 TEU, TF50 (2017) 15 (Brussels: European Commission). 
European Commission (2017b), EU leads the way by eliminating export subsidies ahead of WTO conference in Buenos Aires, Press Release (Brussels: European Commission).

European Commission (2017c), Annex to the Recommendation for a Council Decision authorising the opening of negotiations for a Free Trade Agreement with Australia, COM(2017)472 (Brussels: European Commission).

European Commission (2018), European Commission Draft Withdrawal Agreement on the withdrawal of the United Kingdom of Great Britain and Northern Ireland from the European Union and the European Atomic Energy Community (Brussel: European Commission).

Garland, (Ransley) Victor (1978), 'Australia's Trade Relations with the European Economic Community. Ministerial Statement', Thursday, 16 March (Canberra: House of Representatives).

HM Government (2017a), The United Kingdom's exit from and new partnership with the European Union, Cm 9417 (London: HMSO).

HM Government (2017b), Future customs arrangements, A Future Partnership Paper (London: HM Government).

HM Government (2017c), Northern Ireland and Ireland, Position Paper (London: HM Government).

Hussey, Karen \& Carl Tidemann (2017), 'Agriculture in the Australia-EU economic and trade relationship', in Annmarie Elijah, Donald Kenyon, Karen Hussey \& Pierre van der Eng (eds.) Australia, the European Union and the New Trade Agenda (Canberra: ANU Press).

Joint Report from the Negotiators of the European Union and the United Kingdom Government on Progress During Phase 1 of Negotiations Under Article 50 TEU on the United Kingdom's Orderly Withdrawal from the European Union (2017) 8 December: https://ec.europa.eu/commission/publications/joint-report-negotiatorseuropean-union-and-united-kingdom-government-progress-during-phase1-negotiations-under-article-50-teu-united-kingdoms-orderly-withdrawaleuropean-union en

Keating, Michael (2018), The Repatriation of Competences in Agriculture after Brexit (Edinburg: Centre on Constitutional Change).

Kenyon, Don \& David Lee (2006), The Struggle for Trade Liberalisation in Agriculture: Australia and the Cairns Group in the Uruguay Round, The Foreign Affairs and Trade Files No. 4 (Canberra: Department of Foreign Affairs and Trade).

Lodge, Juliet (1982, The European Community and New Zealand (London: Frances Pinter). 
Mauldon, Roger G. (1990), 'Price Policy', in D. B. Williams (ed.) Agriculture in the Australian Economy, $3^{\text {rd }}$ edition (Sydney: Sydney University Press).

May, Theresa (2017), Statement on the G20 in Hamburg, Hansard, 17 July, Volume 627.

Meat \& Livestock Australia (2017), Submission 49 to the Australian Parliament's Joint Standing Committee on Foreign Affairs, Defence and Trade:

http://www.aph.gov.au/Parliamentary Business/Committees/Joint/Forei gn Affairs Defence and Trade/tradewithUK/Submissions

Moir, Hazel (2017), 'Geographical Indications: An Assessment of EU Treaty Demands', in Annmarie Elijah, Donald Kenyon, Karen Hussey \& Pierre van der Eng (eds.) Australia, the European Union and the New Trade Agenda (Canberra: ANU Press).

Parliament of the Commonwealth of Australia (2017), Joint Standing Committee on Foreign Affairs, Defence and Trade, Inquiry into Australia's trade and investment relationship with the United Kingdom. Interim report (Canberra: Parliament of the Commonwealth of Australia).

Swinbank (2015), 'CAP Reform, 2005-14, and the Muted Role of he DisUnited Kingdom', in Johan Swinnen (ed.) The Political Economy of the 20142020 Common Agricultural Policy: An Imperfect Storm (London: Rowman and Littlefield International).

Swinbank, Alan (2017a), World Trade Rules and the Policy Options for British Agriculture post-Brexit, UK Trade Policy Observatory Briefing Paper 7 (Falmer: University of Sussex).

Swinbank, Alan (2017b), 'Brexit, Trade Agreements, and CAP Reform', EuroChoices, 16(2): 4-9.

Swinbank, Alan \& Carsten Daugbjerg (2017), "The Changed Architecture of the EU's Agricultural Policy Over Four Decades: Trade Policy Implications for Australia', in Annmarie Elijah, Donald Kenyon, Karen Hussey \& Pierre van der Eng (eds.) Australia, the European Union and the New Trade Agenda (Canberra: ANU Press).

Webb, Carole (1977), 'Mr. Cube versus Monsieur Beet: The Politics of Sugar in the European Communities', in Helen Wallace, William Wallace \& Carole Webb (eds.) Policy-Making in the European Communities (London: John Wiley \& Sons).

World Trade Organization (2008), Revised Draft Modalities for Agriculture, TN/AG/W/4/Rev.4 (Geneva: WTO).

World Trade Organization (2016), Certification of Modifications and Rectifications to Schedule CLXXIII - European Union. Transmission of Certified True Copy, WLI/100 (Geneva: WTO). 
Table 1: Australian Exports of Selected Agricultural Products to the EU10

\begin{tabular}{|l|r|r|r|r|}
\hline & \multicolumn{1}{|c|}{$\begin{array}{c}1967-68 \\
1,000 \mathrm{t}\end{array}$} & $\begin{array}{c}1971-72 \\
1,000 \mathrm{t}\end{array}$ & $\begin{array}{c}1977-78 \\
1,000 \mathrm{t}\end{array}$ & $\begin{array}{c}1982-83 \mathrm{p} \\
1,000 \mathrm{t}\end{array}$ \\
\hline Beef \& veal & 25.7 & 42.7 & 17.6 & 8.9 \\
\hline Sheepmeat & 12.1 & 63.8 & 5.5 & 15.5 \\
\hline Wheat & 805.0 & 833.0 & 66.5 & 0.0 \\
\hline Barley & 7.0 & 613.0 & 161.0 & 0.0 \\
\hline Sugar & 400.0 & 528.0 & 28.6 & 0.0 \\
\hline Butter & 57.1 & 11.2 & 2.7 & 0.3 \\
\hline Cheese & 18.5 & 4.4 & 1.5 & 3.1 \\
\hline Apples \& pears & 119.4 & 84.9 & 40.6 & 10.1 \\
\hline $\begin{array}{l}\text { Canned deciduous } \\
\text { fruit }\end{array}$ & 123.0 & 71.2 & 28.6 & 29.7 \\
\hline Dried vine fruit & 39.9 & 26.1 & 15.0 & 27.0 \\
\hline
\end{tabular}

Source: Bureau of Agricultural Economics (1985: 333)

Original data from the Australian Bureau of Statistics and the Australian Meat and Livestock Corporation

$\mathrm{p}=$ preliminary data at the time

Greece became a member of the EU in January 1981

Table 2: The EU's MFN tariffs on selected products and their support prices under the CAP

\begin{tabular}{|l|c|c|}
\hline & $\begin{array}{c}\text { MFN tariff } \\
\text { per tonne }\end{array}$ & $\begin{array}{c}\text { CAP support price } \\
\text { per tonne }\end{array}$ \\
\hline Beef carcass, fresh or chilled & $12.8 \%$ plus $€ 1,768$ & $€ 2,224$ \\
\hline Butter & $€ 1,896$ & $€ 2,463.9$ \\
\hline White sugar & $€ 419$ & $€ 404.4$ \\
\hline
\end{tabular}

During 2017 the average value of the euro (€) was AUS\$1.4732, within the range 1.3689 -

1.5693. 


\section{End Notes}

\section{i https://en.wikipedia.org/wiki/The Troubles}

ii The EEC evolved into today's European Union (EU). This paper refers to either the EEC or the EU as seems more appropriate, rather than attempting to precisely document evolving institutional arrangements and terminology.

iii The latest certified true copy of the modifications and rectifications to this schedule is dated 1 December 2016 (WTO, 2016). On 6 October 2017 the EU submitted a revised schedule to include modifications and rectifications consequent upon Croatia's accession to the EU, and to reflect the WTO decision to eliminate export subsidies on agricultural goods (European Commission, 2017b).

iv This is perhaps an unintended consequence. Under the pre-Uruguay Round system of variable import levies, a reduction in EU support prices (including its minimum import -threshold- prices) would have led to a levy reduction.

v For example: 'bilateral implementation of a technology-based solution for roll-on, roll-off ports which could consist of pre-arrival notification of consignments on a port IT system, linked to customs declarations and vehicle registration numbers so that vehicles were not required to stop at the border, enabling traffic to flow smoothly' (HM Government, 2017b: 9).

${ }^{\text {vi } A s ~ H M ~ G o v e r n m e n t ~(2017 c: 13) ~ n o t e s: ~ ' W h e n ~ c o n s i d e r i n g ~ c r o s s-b o r d e r ~}$ trade, it is particularly important to note the integrated nature of the agrifood sector. Food, beverages and tobacco account for 49 per cent of crossborder manufacturing trade, with, for example, more than 10,000 pigs exported from Ireland to Northern Ireland every week and a quarter of all milk produced on Northern Ireland's farms exported for processing in Ireland' (footnotes omitted).

vii It might be noted that the EU has insisted that a post-Brexit UK should put in place domestic legislation providing for the continued protection of 
existing Geographical Indications of Origin (GIs) 'comparable to that provided by Union law' (European Commission, 2017a).

viii The UK has said that it 'will maintain current access for the Least Developed Countries (LDCS) to UK markets and aim to maintain the preferential access of the remaining (non-LDC) developing countries, including those countries with which we have Economic Partnership Agreements' (HM Government, 2017b: 5). The EU has negotiated Economic Partnership Agreements (EPAs) with the African, Caribbean and Pacific (ACP) states that had preferential access to EU markets through the Lomé and then Cotonou Conventions. 